\title{
Zika virus may be linked to several birth defects, expert warns
}

\author{
Anne Gulland \\ London
}

The Zika virus may be linked to other congenital malformations, not just microcephaly, a Brazilian public health expert has warned.

Paulo Buss, director of the global health centre at the Oswaldo Cruz Foundation in Rio de Janeiro, told a press conference that scientists were still not "aware of all the consequences" of infection with the virus. "The extent to which the epidemic will affect pregnant mothers is not known, nor what the outcome of their babies will be," he said. "Other manifestations may emerge."

Buss said that initial findings from a cohort of pregnant women being studied showed that the virus, spread by the Aedes aegypti mosquito, may be linked to other congenital malformations.

"Some fetuses have shown changes in the brain that have not necessarily been microcephaly. We cannot say for sure that it's only microcephaly [where there's going to be a link]," he said. He said that scientists had not "yet nailed" what the malformations were but that "we're working on it."

Buss was speaking to journalists at the end of a two day Pan American Health Organisation meeting where scientists from around the world gathered to look at the current gaps in the scientific knowledge about the virus.

So far 31 countries and territories in South and Central America have reported circulation of Zika virus, which is thought to be linked to an increase in the number of babies born with microcephaly in Brazil and French Polynesia, though an association has not yet been proved, and an increase in the number of cases of Guillain-Barré syndrome in Colombia, Brazil, Suriname, Venezuela, and El Salvador.

The virus is now spreading in Colombia, with the first cases reported in October, and World Health Organisation and Pan
American Health Organisation officials are on the alert for babies born with birth defects over the coming months.

Marcos Espinal, director of the department of communicable diseases and health analysis at the Pan American Health Organisation, said, "We could be seeing some cases of microcephaly in Colombia in the next few months. Five to six thousand pregnant women have tested positive for Zika, and we're following them very carefully. We think what happens in Colombia is going to tell us a lot about this issue."

Lyle Petersen, director of the division of vectorborne diseases at the US Centers for Disease Control and Prevention, said that in his 25 years of studying vectorborne diseases he had not seen a virus like Zika. "This is the first vectorborne disease to cause infections in the fetus and abnormal birth outcomes. And it's the first vectorborne disease readily spread by sexual means," he said.

He said that health experts had to work out a control strategy that effectively targeted pregnant women.

"Several approaches have been discussed. One is the use of bed nets and indoor spraying, putting up screens, the use of repellent, and even the use of condoms to prevent sexual transmission. All these methods can be employed right now, but we need to figure out what tools are acceptable and whether they actually work," he said.

For The BMSs latest articles on the Zika virus epidemic go to bmj.co/ zika.

Published by the BMJ Publishing Group Limited. For permission to use (where not already granted under a licence) please go to http://group.bmj.com/group/rights-licensing/ permissions 